\title{
Implications of genotype $x$ environment interaction in the indication of common bean cultivars in Santa Catarina, Brazil
}

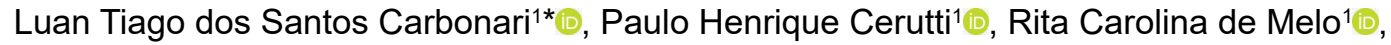 \\ Altamir Frederico Guidolin ${ }^{1}$, Jefferson Luís Meirelles Coimbra ${ }^{1} \mathbb{B}$

\footnotetext{
1 Universidade do Estado de Santa Catarina, Lages, SC, Brasil. E-mail: carbonari.luan@gmail.com; paulohcerutt@@gmail.com; rita_carol_mel@hotmail.com; altamirguidolin@gmail.com; coimbrajefferson@gmail.com
}

ABSTRACT: The objective of the work was to verify the effect of the genotype $x$ environment interaction and its implication in the recommendation of bean genotypes in the first and second crop in Santa Catarina, together with the simultaneous diagnosis of productive and stable genotypes. The data come from the state and southern Brazilian tests of lines and cultivars conducted in the state, totaling twenty-four environments and forty-eight genotypes of beans, which were evaluated in the conditions of first and second crop (12 environments each), in agricultural years 2012/13, 2013/14 and 2014/15. The analyzes were divided into the two cultivation conditions, using the model of main additive effects and multiplicative interaction. The first crop showed a greater effect of the genotype $x$ environment interaction on the total variation, compared to the second. The genotypes showed stability to few environments, with favorable or unfavorable association of grain yield. The stable genotype with the highest production in the first crop condition was 46 and 26 in the second.

Key words: AMMl; Phaseolus vulgaris L.; stability; yield

\section{Implicações da interação genótipo $x$ ambiente na indicação de cultivares de feijão em Santa Catarina, Brasil}

RESUMO: O objetivo do trabalho foi verificar o efeito da interação genótipo x ambiente e sua implicação na recomendação de genótipos de feijão na primeira e segunda safra em Santa Catarina, conjuntamente ao diagnóstico simultâneo de genótipos produtivos e estáveis. Os dados são provenientes dos ensaios estadual e sul brasileiro de linhagens e cultivares conduzidos no estado, totalizando vinte e quatro ambientes e quarenta e oito genótipos de feijão, que foram avaliados nas condições de primeira e segunda safra (12 ambientes cada), nos anos agrícolas de 2012/13, 2013/14 e 2014/15. As análises foram divididas nas duas condições de cultivo, utilizando o modelo de efeitos principais aditivos e interação multiplicativa. A primeira safra apresentou maior efeito da interação genótipo x ambiente na variação total, em comparação a segunda. Os genótipos apresentaram estabilidade a poucos ambientes, com associação favorável ou desfavorável do rendimento de grãos. 0 genótipo estável com maior produção na condição de primeira safra foi o 46 e na segunda 026.

Palavras-chave: AMMI; Phaseolus vulgaris L.; estabilidade; rendimento

\footnotetext{
* Luan Tiago dos Santos Carbonari - E-mail: carbonari.luan@gmail.com (Corresponding author)

Associate Editor: Alberto Cargnelutti Filho
} 


\section{Introduction}

Foods from leguminous plants are considered important for diverse, healthy, and nutritious diets. Because of these characteristics, the common bean (Phaseolus vulgaris L.) is widely cultivated. In Brazil, the average productivity of this type of bean is approximately $1500 \mathrm{~kg} \mathrm{ha}^{-1}$, considered to be below the crop's potential (Conab, 2021). In Santa Catarina the sowing occurs in two seasons, first crop from September to November and the second from January to February (Kavalco et al., 2018).

Grain yield is affected by many abiotic factors, such as water stress, low or high temperatures, and nutritional deficiencies (Konzen et al., 2019). This scenario is further aggravated by the fact that most of the cultivation is carried out by family farmers, in large proportion with low input addition. Such characteristics of the production environments favor the relative performance of the genotypes.

The differential effect of the production of these genotypes, in the different environments, is conceptualized as genotype $\times$ environment interaction (Falconer \& Mackay, 1996). This variation in production may be due to the polygenic control of the trait, leading to the occurrence of a distinct reaction to changes in the environment, resulting in different environment-induced interactions in the regulation and gene expression of the genotypes (Berny Mier $Y$ Teran et al., 2020).

Thus, the genotype $x$ environment interaction represents one of the greatest difficulties for the breeder, evidenced in the final phase of breeding programs. In previous studies for the bean crop in Santa Catarina, these demonstrate close genetic variability for the grain yield character in the genotypes evaluated and a wide variation of environments (Bertoldo et al., 2009). Thus, alternatives to this scenario are related mainly to the use of stable genotypes, since these present as a characteristic a constant production in different environments (Falconer \& Mackay, 1996).

Therefore, the study of this interaction and its correct interpretation comprises a possibility for the consistent indication of genotypes with high yields, for general or specific environments. In this sense, tests are carried out at the time of evaluation of the genotypes, since they are submitted to comparative trials, in the final phase of the breeding programs. The objective is the correct and reliable recommendation of cultivars with better performance to certain regions (Ramalho et al., 1993).

Toward this goal, trials are conducted in multiple environments (year and locations). However, when interaction is found to be present, analyzing and interpreting the results additively becomes difficult (Gauch, 2013). The difficulty of interpretation stems from the problem of obtaining estimates of the magnitude of the interaction, since the growing regions are extensive and so are the genetic differences between the genotypes.

Based on this context, the study aimed to verify the effect of the interaction genotype $x$ environment and its implication in the recommendation of bean genotypes, along with the simultaneous diagnosis of stable and productive genotypes, in the first and second crop in the state of Santa Catarina.

\section{Materials and Methods}

The information for the execution of this work comes from the state and South Brazilian trials of Value for Cultivation and Use, of bean lines and cultivars. These trials are coordinated by the Empresa de Pesquisa Agropecuária e Extensão Rural de Santa Catarina (EPAGRI). The character under study is grain yield $\left(\mathrm{kg} \mathrm{ha}^{-1}\right)$, from trials conducted in 9 cities in Santa Catarina, Brazil, being: Chapecó (CH), Canoinhas (CA), Campos Novos (CN), Águas de Chapecó (AC), Ponte Serrada (PS), Xanxerê (XA), Ituporanga (ITU), Urussanga (UR), and Lages (LA), during three agricultural years 2012/13 (13), 2013/14 (14) and 2014/15 (15), totaling 24 environments, and a total of 48 genotypes were evaluated in these environments.

The experimental design used was randomized blocks with four repetitions. The experimental unit was composed of four rows, four meters long, with uniform inter-row spacing of $0.45 \mathrm{~m}$ and sowing density of 15 seeds per linear meter. The usable area of each experimental unit was composed of the two central rows, excluding the two outer rows, in order to minimize border effects. The sowing and top dressing fertilizations were based on the interpretation of the soil analysis, following the technical recommendations for the crop.

The additive and multiplicative interaction main effects model (AMMI) analysis, was performed according to Gauch (2013), with the model:

$$
Y_{i j k}=\mu+e_{j}+b e_{j}+g_{i}+\sum_{k=1}^{n} \lambda_{k} \gamma_{i k} \alpha_{j k}+\rho_{i j}+\varepsilon_{i j k}
$$

where $Y_{i j k}$ is the observation in the $i$-th genotype ( $i=1,2,3$, $\ldots, g)$, evaluated in the $k$-th block $(k=1,2,3,4)$, in the $j$-th environment $(j=1,2,3, \ldots, e) ; \mu$ is the average of all genotypes in all environments (overall average); $e_{j}$ is the main effect of environment $\mathrm{j}$; be $\mathrm{b}_{\mathrm{j}}$ is the effect of blocks, in the $\mathrm{j}$ environments; $\mathrm{g}_{\mathrm{i}}$ is the main effect of genotype $\mathrm{i} ; \lambda_{\mathrm{k}}, \gamma_{\mathrm{ik}}$ and $\alpha_{\mathrm{jk}}$ are the singular decomposition (DVS) terms of the matrix $\mathrm{GE}_{\mathrm{gxe}}=\left\{(\mathrm{ge})_{\mathrm{ij}}\right\}$, that express and capture the model associated with the interaction of genotype $\mathrm{i}$ with environment $\mathrm{j}$, where is (ge $)_{\mathrm{ij}}$ the additivity deviations of the data $\left(Y_{i j}\right)$ in relation to the main effects $g_{i}$ and $e_{j} ; \rho_{i j}$ is an additional noise to be eliminated in the analysis, relative to the $(\mathrm{ge})_{\mathrm{ij}}$ term, traditionally taken as the interaction itself; $\varepsilon_{\mathrm{ijk}}$ is the average experimental residual.

The breakpoint determining AMMI model selection (PCA1, PCA2, ..., PCAn) was obtained based on F-test significance for successive interaction terms, pooling the remaining terms not retained in the selected model into complementary portions of $\mathrm{SS}_{\mathrm{G} \times \mathrm{E}}$ by F-test. Based on the analysis of variance, the genetic variance component was estimated $\left(\sigma_{\mathrm{g}}{ }^{2}\right)$ and $\mathrm{G} \times \mathrm{E}$ interaction $\left(\sigma_{\mathrm{ge}}{ }^{2}\right)$, by the following expressions: 


$$
\sigma_{\mathrm{g}}^{2}=\left(\mathrm{MS}_{\mathrm{G}}-\mathrm{MS}_{\mathrm{GE}}\right) \mathrm{be}^{-1}
$$

and

$$
\sigma_{\mathrm{ge}}^{2}=\left(\mathrm{MS}_{\mathrm{E}}-\mathrm{MS}_{\mathrm{R}}\right) \mathrm{b}^{-1}
$$

where: $\mathrm{MS}_{G}$ : is the mean square of genotypes; $\mathrm{MS}_{G E}$ : is related to the $G \times E$ interaction; $M_{E}$ : referring to the mean square of the environment; $\mathrm{MS}_{\mathrm{R}}$ : is the residual mean square; e: number of environments; $b$ : is the number of blocks (Cruz, 2005).

The potential yield loss due to the $\mathrm{G} \times \mathrm{E}$ interaction was estimated following the expression:

$$
\mathrm{C}=1-\left[\frac{\left(\sigma_{\mathrm{g}}{ }^{2}+\sigma^{2}\right)^{\frac{1}{2}}}{\left(\sigma_{\mathrm{g}}{ }^{2}+\sigma_{\mathrm{ge}}{ }^{2}+\sigma^{2}\right)^{\frac{1}{2}}}\right]
$$

where, $\mathrm{C}$ is the potential productivity loss; $\sigma_{\mathrm{g}}{ }^{2}$ is the genetic variance component; $\sigma_{\mathrm{ge}}{ }^{2}$ is the variance component of the interaction; and, $\sigma^{2}$ is the variance of the residual. The stability index by AMMI (ASV) was calculated using the following formula:

$$
\mathrm{ASV}=\left\{\left[\left(\frac{\mathrm{SS}_{\mathrm{PC} 1}}{\mathrm{SS}_{\mathrm{PC} 2}}\right) \cdot(\mathrm{PC} 1)\right]^{2}+\mathrm{PC}^{2}\right\}^{\frac{1}{2}}
$$

where, ASV is the AMMI stability value; $\mathrm{SS}_{\mathrm{PC1}}$ and $\mathrm{SS}_{\mathrm{PC} 2}$ is the sum of squares of the first and second interaction axis; PC1 and PC2 are the genotype scores from the AMMI model. Analyses were performed in two steps: initially for first crop and later for second crop, with 12 environments inherent to each, using R software (R Core Team, 2018).

\section{Results and Discussion}

The analysis of variance for the first crop, in 12 environments with 48 genotypes (Table 1), revealed significance for environments and genotypes $(p<0.05)$, along with genotype $x$ environments interaction $(G \times E)$. Environments showed variation approximately 25 times greater than genotype variation and $57 \%$ of the sum of squares (SS) explained. Genotypes and $\mathrm{G} \times \mathrm{E}$ interaction show consecutively 9.5 and $17.7 \%$ of the SS, the effect of blocks within environments represented $1.3 \%$ of the sum of squares. The percentage explained of the residual is $13.5 \%$, a value reflected by the model's coefficient of variation (CV) of $18.6 \%$. The genotypic variance component $\left(\sigma_{\mathrm{g}}{ }^{2}\right)$ was 47396 , approximately 5.3 times $\left(\sigma_{\mathrm{ge}}{ }^{2} / \sigma_{\mathrm{g}}{ }^{2}\right)$ smaller than the $\mathrm{G} \times \mathrm{E}$ interaction component $\left(\sigma_{\mathrm{ge}}{ }^{2}\right)$, estimated at 254826 .

The second crop had 12 environments and 39 genotypes, and differences $(p<0.05)$ were observed for genotypes,
Table 1. Analysis of variance and AMMI model for first crop, for 48 bean genotypes in 12 environments, evaluated for yield in $\mathrm{kg} \mathrm{ha}^{-1}$.

\begin{tabular}{lcccc}
\hline \multicolumn{1}{c}{ Cause of variation } & DF & MS & PE (\%) & PA (\%) \\
\hline Environments & 11 & $92365345^{*}$ & 57 & - \\
Blocks (Environment) & 36 & 656618 & 1.3 & - \\
Genotypes & 47 & $3555937^{*}$ & 9.5 & - \\
G $\times$ E interaction & 243 & $128091^{*}$ & 17.7 & - \\
PC1 & 57 & $3035082^{*}$ & 55.5 & 55.5 \\
PC2 & 55 & $692468^{*}$ & 12.2 & 67.7 \\
PC3 & 53 & $425440^{*}$ & 7.2 & 74.9 \\
PC4 & 51 & $389867^{*}$ & 6.4 & 81.3 \\
PC5 & 49 & 269304 & 4.2 & 85.5 \\
$\ldots$ & $\ldots$ & $\ldots$ & $\ldots$ & $\ldots$ \\
PC11 & 37 & 64753 & 0.8 & 100 \\
Residue & 910 & 261614 & 13.5 & - \\
$\sigma_{g}{ }^{2}=47396$ & $\sigma^{2}=261614$ & \multicolumn{3}{c}{ Mean $=2746 \mathrm{~kg} \mathrm{ha}^{-1}$} \\
$\sigma_{\mathrm{ge}}{ }^{2}=254826$ & $\mathrm{C}=0.26$ & \multicolumn{3}{c}{ CV (\%) $=18.62$} \\
\hline
\end{tabular}

* Significant at 5\% probability, by the $\mathrm{F}$ test; DF: degrees of freedom; MS: mean squares; PE: proportion of the sum of squares explained; PA: proportion of cumulative sum of squares; $\sigma_{\mathrm{g}}{ }^{2}$ : component of genotypic variance; $\sigma_{\mathrm{ge}}{ }^{2}$ : variance component of the $\mathrm{G} \times \mathrm{E}$ interaction; $\sigma^{2}$ : residual variance; C: potential yield loss by the $G \times E$ interaction; $C V$ : coefficient of variation.

environments and $\mathrm{G} \times \mathrm{E}$ interaction (Table 2). The percentage explained of the sum of squares (SS) for environments was $65 \%$, with an increase in this proportion compared to the first crop. Furthermore, there is a reduction in the proportion of genotypes and $\mathrm{G} \times \mathrm{E}$ interaction, with consecutive values of 6.8 and $11.2 \%$. Table 2 demonstrates a reduction in the value of the genotypic variance $\left(\sigma_{\mathrm{g}}{ }^{2}\right)$, so that the buffering variations of the genotypes' production in different environments are minimized. However, the interaction variance component $\left(\sigma_{\mathrm{ge}}{ }^{2}\right)$ also showed a lower value in the second crop compared to the first crop, and this value was approximately 3.7 times greater than the genotypic variance $\left(\sigma_{\mathrm{ge}}{ }^{2} / \sigma_{\mathrm{g}}{ }^{2}\right)$.

The results show an inconsistency in the relative performance of the genotypes from one environment to the other, given the significance of the $G \times E$ interaction. However, the overall effects of genotypes are also significant,

Table 2. Analysis of variance and AMMI model for second crop, for 39 bean genotypes in 12 environments, evaluated for yield in $\mathrm{kg} \mathrm{ha}^{-1}$.

\begin{tabular}{lcccc}
\hline \multicolumn{1}{c}{ Cause of variation } & DF & MS & PE (\%) & PA (\%) \\
\hline Environments & 11 & $34500488^{*}$ & 65 & - \\
\hline Blocks (Environment) & 36 & 406337 & 2.5 & - \\
Genotypes & 38 & $1047865^{*}$ & 6.8 & - \\
G $\times$ E interaction & 190 & $342137^{*}$ & 11.2 & - \\
PC1 & 48 & $445690^{*}$ & 32.7 & 32.7 \\
PC2 & 46 & $325235^{*}$ & 22.8 & 55.5 \\
PC3 & 44 & 139541 & 9.4 & 64.9 \\
$\ldots$ & $\ldots$ & $\ldots$ & $\ldots$ & $\ldots$ \\
PC11 & 28 & 13058 & 0.6 & 100 \\
Residue & 682 & 124262 & 14.5 & - \\
$\sigma_{\mathrm{g}}{ }^{2}=14702$ & $\sigma^{2}=124262$ & & Mean $=2202 \mathrm{~kg} \mathrm{ha}^{-1}$ \\
$\sigma_{\mathrm{ge}}{ }^{2}=54468$ & $\mathrm{C}=0.15$ & & $\mathrm{CV}(\%)=16.00$ \\
\hline
\end{tabular}

* Significant at $5 \%$ probability, by the $\mathrm{F}$ test; DF: degrees of freedom; MS: mean squares; $\mathrm{PE}$ : proportion of the sum of squares explained; PA: proportion of cumulative sum of squares; $\sigma_{g}^{2}$ : component of genotypic variance; $\sigma_{g e}^{2}$ : variance component of the $G \times E$ interaction; $\sigma^{2}$ : residual variance; $C$ : potential yield loss by the $\mathrm{G} \times \mathrm{E}$ interaction; $\mathrm{CV}$ : coefficient of variation. 
and some of these can be indicated in a generalized way for all environments and not only with restricted interest in one location. The proportion of the sum of squares of environments, analyzed in the first and second crops were equivalent to 57 and $65 \%$, implying that much of the additive effects of the model are related to the environmental component. The magnitude of these values, is evidenced as the main factor of influence for the bean genotypes tested in the state of Santa Catarina, Brazil, being also reported by Bertoldo et al. (2009).

The cause of variation genotypes, presented 9.5 and $6.8 \%$ consecutively, of the percentage explained by the sum of squares, for the first and second crop. The $G \times E$ interaction observed in the additive model, demonstrates that the analyses in the two growing seasons correspond to different magnitudes of interaction. This is because the genotypes interact with a greater number of environments for the first crop. Looking at the variance components, different ratios of $G$ $\times E$ interaction variance, per genotypic variance, are found. In the second crop this ratio is lower (3.7), inferring the presence of more pronounced general genotype effects, compared to the first (5.3). In this way, it is possible to indicate a larger number of genotypes related to different environments for the second crop condition.

In this sense, the genotypes in the first crop have higher proportions of $G \times E$ interaction explained by the sum of squares compared to the second crop. The explained percentage of the $\mathrm{G} \times \mathrm{E}$ interaction, for the distinct growing seasons, matches those reported by Gauch (2013), this author reports a frequency in the range of 10 to $20 \%$ of the sum of squares, attributed to the $\mathrm{G} \times \mathrm{E}$ interaction component. However, in practical situations the researcher has the interest directed beyond the knowledge of the magnitude of the $\mathrm{G} \times \mathrm{E}$ interaction. It is important to know whether or not there are different classifications of genotypes.

Thus, in addition to variance ratios $\left(\sigma_{\mathrm{ge}}{ }^{2} / \sigma_{\mathrm{g}}{ }^{2}\right)$, the average yields of the genotypes tied to potential grain yield losses are relevant. The average yield in the first crop (2746 kg ha-1) was approximately $25 \%$ higher than the second $(2202 \mathrm{~kg}$ ha $\left.{ }^{1}\right)$. This lower productivity observed in the second crop can be attributed mainly to the occurrence of high temperatures during flowering and pod formation, which intensifies the abortion of flowers and pods (an important yield component of the crop). Together with a better distribution of rainfall during the first crop season, favoring higher grain yields (Carbonell et al., 2004).

However, in addition to higher grain yield, the first crop also showed higher potential yield loss (C) inherent in the $G$ $\times E$ interaction. This value is approximately 0.25 for this crop condition (Table 1), compared to 0.15 for the second crop condition (Table 2). With this, in the first crop the genotypes suffer yield oscillations with greater intensity, inherent to the $\mathrm{G} \times \mathrm{E}$ interaction term. These oscillations in percentage terms are in the range of $25 \%$ in the first and $15 \%$ in the second crop. Thus, this fact can be attributed mainly to the environment conditions, because in the first one where the yield is higher, consequently the yield fluctuations of the genotypes are also higher, inherent of the interactions of these with the environments favorable and unfavorable to grain yield.

The magnitude of these variations captured by the $G$ $\times E$ interaction, has as a basic implication a difficulty in interpreting the additive terms of the model, which results in an inconsistent ordering of the genotypes in the different environments. Due to changes in ranking, the focus is mainly on whether the best genotype in one environment is also the best in another, implying that relative characterizations and comparisons of the genotypes (rankings) are more important than absolute characterizations and comparisons. Based on this context, Eisemann et al. (1990) emphasize that there are at least three ways to mitigate the $G \times E$ interaction, being: i) identifying specific cultivars for each environment; ii) performing ecological zoning; and, iii) identifying cultivars with greater phenotypic stability.

In general, the adaptability and stability of a cultivar is intrinsically related to its genetic constitution, that is, to the sum of genes that constitute this genotype. This fact results in the characteristics of phenotypic plasticity, composed of the modification of the phenotype that occurs at the expense of the genotype. In practical terms it is the ability to respond to environmental changes and adaptation, which allows the genotype to withstand an environmental stress (Konzen et al., 2019; Lyon et al., 2020).

Falconer \& Mackay (1996) report a difficulty in interpretation, when considering only as one character, the measurement of a certain character in two different environments. Because the physiological mechanisms that act in different environments are not the same. Considering the $G \times E$ interaction present, since its significance, the singular value decomposition (SVD) adjustment was performed. This technique is applied in order to obtain results derived from a matrix with smaller dimensions.

Parallel to the use of this technique, the unfolding of the sums of squares, for model validation, is observed on the respective axes of the principal components (PC) for the first and second crops (Table 1 and 2). These captured an explained proportion of the SS of the interaction successively of $55,12,7.2$, and $6.4 \%$, totaling a cumulative proportion of $81 \%$ for the first crop, with the remaining unfoldings not significant by the F-test at $5 \%$ error probability. In the second crop condition, significance by the F-test at $5 \%$ is seen in the first two components, with successive proportions of 32.7 and $28.8 \%$.

Thus, with the significance of the components we proceeded to graphical representation by means of two dimensions, using the graphs called biplot for the understanding of the $G \times E$ interaction. In this work, the abscissa axis was used to represent the first component (PC1) and the ordinate axis to represent the effect of the means of genotypes and environments. With this visualization it is possible to obtain adaptive inferences, considering the grain yield of the genotypes. Also of relevance is the identification of constant environments that are favorable or not favorable for 
grain production. For, the evaluation of genotypes in constant environments infer that the differential effects observed are mainly due to genetic variation.

With Figure 1 , it is possible to observe the relationship of CP1 and Productivity (Y) for the first crop, the environment PS14 (Ponte Serrada 2013/14) presents low stability, favoring the differential performance of the genotypes tested. The test genotypes at this location, showed a similar behavioral trend. This fact is due to the greater variation in the environment, which contributes effectively to the sum of squares of the interaction. The LA14 environment (Lages 2013/14) demonstrates a behavior in this sense, favoring the differential response of the genotypes.

Such behaviors are propitiated mainly by the variation present at each site, that is, the greater the variation, the less stable is the site. This concept is easy to interpret, when we imagine that different responses of genotypes, in a given environment, come from many micro-environments constituting the macro-environment (Environment). With this, the variation within the genotypes presents a great magnitude due to the environmental differences, which makes it difficult to differentiate them, regarding their higher or lower production.

The genotypes with the highest average yield $Y\left(\mathrm{~kg} \mathrm{ha}^{-1}\right)$ in the first crop are located in the upper part of the graph (Figure 1), with 41, 38, 40, and 42. Above-average yield (line perpendicular to the $Y$ yield axis), is observed in genotypes $21,22,19,24,32,17,30,27,20$, and 26, however they are less stable, whereas, they correlate with environments CA14 (Canoinhas 2013/14) and LA14 (Lages 2013/14). Lower than average yield and lower stability was observed in genotypes 36, 35, 11, and 13. Environments PS13 (Ponte Serrada 2012/13) and CA13 (Canoinhas 2012/13), demonstrate a greater contribution to productivity, linked to the stability of the genotypes. In parallel, LA15 (Lages 2014/15), PS15 (Ponte Serrada 2014/15) and CN14 (Campos Novos 2013/14), are stable, however with lower production stimuli, situated below average.

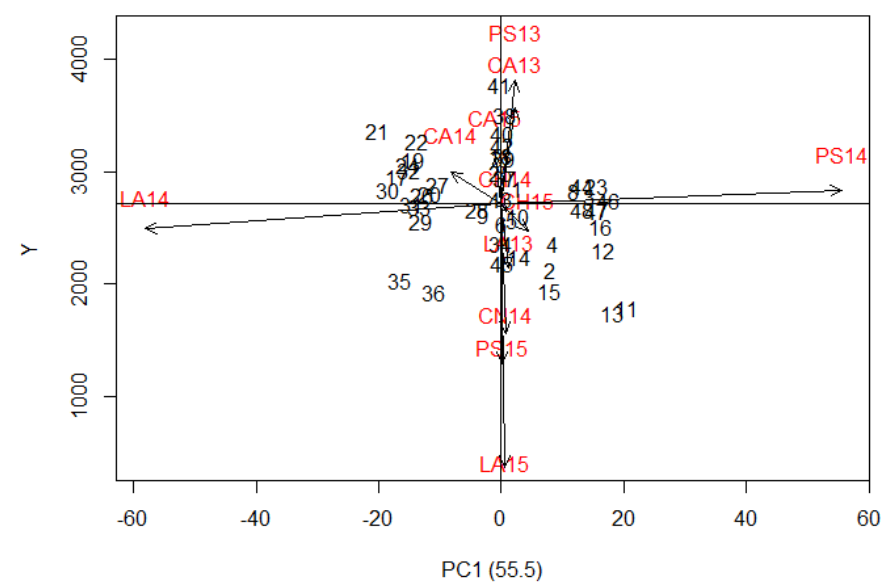

Figure 1. Biplots of the AMMI model for first crop, elucidating the effects of the primary component (PC1) and yield in $\mathrm{kg} \mathrm{ha}^{-1}(\mathrm{Y})$.
Figure 2, shows that the genotypes with the highest yields, coupled with good stability by visual biplot analysis are 39,35 , 38 , and 18 . The environments with above average production rates are AC15 (Águas de Chapecó 2015), IT14 (Ituporanga 2014), IT13 (Ituporanga 2013), XA15 (Xanxerê 2015), CN14 (Campos Novos 2014) and CH13 (Chapecó 2013), the latter two being superior as to production and stability, relative to PC1. The UR14 environment (Urussanga 2014) shows a lower production rate. The use of favorable or unfavorable environments for production when evaluating and analyzing genotypes has already been discussed in the literature.

Some authors point out that the testing of genotypes in environments that favor production is of utmost importance, so that genotypes can express their productive potential (Whitehead \& Allen, 1990). However, others advocate testing genotypes in unfavorable environments, arguing a possible greater ability to indicate the most promising genotypes (Ceccarelli \& Grando, 1991). Both conceptions are valid, especially when we look at the different agricultural scenarios.

A test in stable environments favorable to production can be advantageous, taking into consideration, the indication of genotypes adapted to environments that provide their maximum performance. Thus, the possible locations for a grouping (use information already available, aiming at a targeted analysis), aiming at the indication of genotypes in this sense, may be Ponte Serrada (PS13) and Canoinhas (CA13), for the first crop, the second indicates the environment of Chapecó ( $\mathrm{CH} 13$ and $\mathrm{CH} 14)$. Besides performance, a positive point for a correct indication of genotypes based on this situation would be that the genotypic variance $\left(\sigma_{\mathrm{g}}^{2}\right)$ is evidenced, in relation to the $G \times E$ interaction variance $\left(\sigma_{\mathrm{ge}}{ }^{2}\right)$, which would enable the indication of genotypes with a greater phenotypic plasticity.

However, the opposite can also be advantageous, since a considerable fraction of farmers are not provided with favorable environments based on controllable characteristics. These controllable characteristics can be, for example, investments in fertility and irrigation, stemming from a limited availability of financial resources. In this context, the first crop

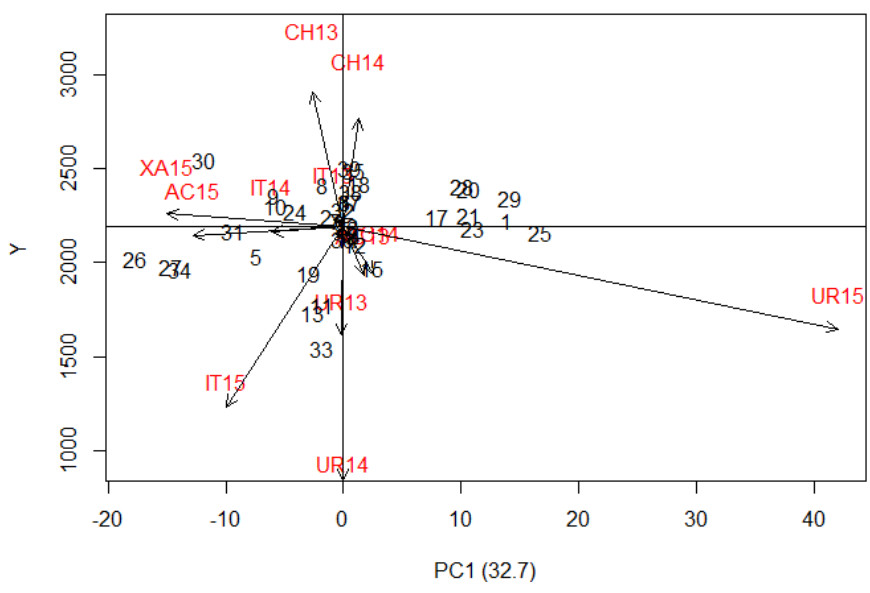

Figure 2. Biplots of the $A M M I$ model for second crop, demonstrating the effects of the primary component (PC1) and yield in $\mathrm{kg} \mathrm{ha}^{-1}(\mathrm{Y})$. 
indicates the environment Lages in the year 2015 (LA15) and the second Urussanga in the year 2014, to be mined (Cluster Analysis), aiming at an identification of superior genotypes in stable and unfavorable environments for production.

The indication of genotypes, based on this environmental condition is relevant mainly when the objective is to identify stable genotypes. Thus, the recommendation for grain yield, using information from trials conducted under unfavorable conditions, tends the genotypes to be less sensitive to changes in environments, compared to those tested for grain yield under stable conditions and favorable to production.

The concept of stability observed in the biplots (Figure 1 and 2 ) is derived primarily from conceptions of homeostasis, used in quantitative genetics, and can be considered a biological or static concept of stability. This concept is characterized by the predictable response of the genotype, i.e. a stable production in all environments, resulting from adaptations of physiological functions, or the maintenance of these aspects, in the face of environmental changes (Becker \& Leon, 1988).

Traditionally, most breeders, since the first conceptions, use the term stability aiming at the characterization of genotypes that demonstrate a constant yield, regardless of the environmental conditions they are submitted to. However, this information is often not desired, because many times the performance of the genotype does not follow the improvement of the environment, and stability may be associated with an intermediate grain yield in certain environments, especially favorable ones (Ramalho et al., 1993).

In this way, the indications of only the stability of the genotypes, with stable production in different environments, can be explored as a recommendation index for farmers with less technological availability, since this is characterized by constant production in different environments, due to the small variation of the genotypes in the face of environmental changes. This trait can ensure a relatively constant yield, however the response of these genotypes to favorable environmental stimuli is limited in some cases. Its singular use can be considered inconvenient for areas favorable to production and with high technological level, such as areas with irrigation and high investments in fertility and precision agriculture (Becker \& Leon, 1988; Pereira et al., 2014).
In contrast, the adaptive relationships of the genotypes in the different environments can be observed based on their degrees with the environmental vectors. Genotypes and environments with the same sign of scores interact positively, demonstrating an adaptive synergism to be taken advantage of at the time of recommendation, and the indication may be regionalized. This characteristic can be conceptualized as adaptability (Becker \& Leon, 1988). Although most $\mathrm{G} \times \mathrm{E}$ interaction studies demonstrate importance for breeding, many present inconclusive information about the behavior of genotypes as a function of environmental changes.

To circumvent this situation, stability and adaptability analyses are widely employed, with the objective of simplifying or extracting more information about the genotypic behavior of the genotypes to be studied and recommended (Eze et al., 2020; Freiria et al., 2020; Inabangan-Asilo et al., 2019; Munda et al., 2020; Mwiinga et al., 2020; Nascimento et al., 2020; Sarti et al., 2020). Based on this, the indication taking into account adaptability, considers the increase in grain yield, arising from the $\mathrm{G} \times \mathrm{E}$ interaction. Thus, the genotypes present desirable performance, responding to environmental improvements, and can be considered at the time of recommendation.

These indications can be seen in Figure 1 in the first crop, where genotype 41 showed association with environments PS13 and CA13, and in the second crop (Figure 2), with the association of genotypes 39 and 38 to $\mathrm{CH} 13$ and $\mathrm{CH} 14$. These genotypes, present as characteristics responses in productivity, to increments in the improvement of environments that are associated with their production. According to the results demonstrated, genotypes are often observed to exhibit adaptability to specific environments or also agronomic stability (Volpato et al., 2020).

In this sense, aiming to identify cultivars with stability in the agronomic sense, Table 3 shows the stability values derived AMMI model (ASV) and its classification, for the genotypes in the first and second crop. A lower ASV score indicates more stable genotypes across environments (Nowosad et al., 2017; Bocianowski et al., 2019). Thus, according to the (rASV) classification, in the first crop the five most stable genotypes were $48,31,25,14$, and 46 , while in the second crop those classified as most stable were $21,3,11,4$, and 26.

Table 3. AMMI stability values (ASV), AMMI stability value classification (rASV) and average yield ( $\mu$ ) in $\mathrm{kg}^{-1}$ of 10 bean genotypes with higher stability for first and second crop in the state of Santa Catarina.

\begin{tabular}{|c|c|c|c|c|c|c|c|}
\hline \multicolumn{4}{|c|}{ First crop } & \multicolumn{4}{|c|}{ Second crop } \\
\hline Genotype & ASV & rASV & $\mu$ & Genotype & ASV & rASV & $\mu$ \\
\hline 48 & 0.15 & 1 & 2758 & 21 & 0.37 & 1 & 2125 \\
\hline 31 & 0.15 & 2 & 2987 & 3 & 0.49 & 2 & 2195 \\
\hline 25 & 0.33 & 3 & 3139 & 11 & 0.72 & 3 & 2219 \\
\hline 14 & 0.99 & 4 & 2539 & 4 & 1.34 & 4 & 2282 \\
\hline 46 & 1.09 & 5 & 3770 & 26 & 1.85 & 5 & 2419 \\
\hline 6 & 1.38 & 6 & 2188 & 40 & 2.62 & 6 & 1544 \\
\hline 4 & 1.84 & 7 & 2363 & 6 & 2.86 & 7 & 2124 \\
\hline 47 & 2.30 & 8 & 3230 & 23 & 2.89 & 8 & 2184 \\
\hline 45 & 5.69 & 9 & 3339 & 2 & 3.02 & 9 & 2096 \\
\hline 44 & 7.57 & 10 & 3113 & 12 & 3.74 & 10 & 2151 \\
\hline \multicolumn{4}{|c|}{ Mean $=2746 \mathrm{~kg} \mathrm{ha}^{-1}$} & \multicolumn{4}{|c|}{ Mean $=2202 \mathrm{~kg} \mathrm{ha}^{-1}$} \\
\hline
\end{tabular}


Although the different stability statistics generally indicate intermediate grain yield performance associated with stable genotypes. These are indispensable, since farmers usually choose to sow genotypes with good yields, but which show considerable stability in the different environments (Kavalco et al., 2018). For this purpose, the ASV parameter can be a useful tool, aiming at the simultaneous indication of yield and stability. Based on the average yield of the first crop $(2746 \mathrm{~kg}$ $\left.\mathrm{ha}^{-1}\right)$, the five genotypes with greater stability show production above this average, with the exception of genotype 14, which shows yields below the average. In the second crop, most genotypes classified as stable, have yields close to the average (2202 kg ha-1).

Considering the stability together with the average yield, in the five most stable genotypes, in the first crop the genotype 46 presents an average of $3770 \mathrm{~kg} \mathrm{ha}^{-1}$, in the second crop the genotype 26 shows an average yield of $2419 \mathrm{~kg} \mathrm{ha}^{-1}$, that is, a proportion of 1.55 times greater yield in the first crop than in the second crop, in the most stable genotype for these conditions. As noted, the indication of stable genotypes with above-average production is likely to be realized. Thus, given the magnitude of the $\mathrm{G} \times \mathrm{E}$ interaction in the bean crop observed in the work for the state, it is relevant to consider yield and performance stability of genotypes in different environments. These traits need further detailing, aiming to explore the useful effects of the $\mathrm{G} \times \mathrm{E}$ interaction, thus making the indication of the genotypes more precise and refined.

\section{Conclusion}

The first crop presents a greater effect of the interaction genotype $x$ environment and more pronounced potential for reduction of productivity of the genotypes, in relation to the second crop. Stability of genotypes is observed in a few environments, regardless of whether they are favorable or unfavorable for grain yield. For the first crop, genotype 46 showed higher production along with stability, for the second crop condition the genotype with these characteristics was 26.

\section{Compliance with Ethical Standards}

Author contributions: Conceptualization: LTSC, JLMC, AFG, RCM, PHC; Data curation: LTSC, JLMC, PHC; Formal analysis: LTSC, JLMC; Funding acquisition: JLMC, AFG; Investigation: LTSC, RCM, PHC; Methodology: LTSC, JLMC, AFG, RCM, PHC; Project administration: LTSC, JLMC, AFG, RCM, PHC; Resources: JLMC, AFG; Software: LTSC, JLMC, AFG, RCM, PHC; Supervision: JLMC, AFG; Validation: LTSC, JLMC, AFG, RCM, PHC; Visualization: LTSC, RCM; Writing - original draft: LTSC; Writing - review \& editing: LTSC, JLMC, AFG, RCM, PHC.

Conflict of interest: The authors declare that there are no conflicts of interest.

Financing source: This study was funded by CNPq (National Council for Scientific and Technological Development) and FAPESC (Foundation for the Support of Research and Innovation of the State of Santa Catarina).

\section{Literature Cited}

Becker, H. C.; Leon, J. Stability analysis in plant breeding. Plant Breeding, v. 101, n. 1, p. 1-23, 1988. https://doi. org/10.1111/j.1439-0523.1988.tb00261.x.

Berny Mier y Teran, J. C.; Konzen, E. R.; Palkovic, A.; Tsai, S. M.; Gepts, P. Exploration of the yield potential of Mesoamerican wild common beans from contrasting eco-geographic regions by nested recombinant inbred populations. Frontiers in Plant Science, v. 11, e346, 2020. https://doi.org/10.3389/fpls.2020.00346.

Bertoldo, J. G.; Coimbra, J. L. M.; Guidolin, A. F.; Nodari, R. O.; Elias, H. T.; Barili, L. D.; Rozzetto, D. S. Rendimento de grãos em feijão preto: o componente que mais interfere no valor fenotípico é o ambiente. Ciência Rural, v. 39, n. 7, p. 1974-1982, 2009. https:// doi.org/10.1590/S0103-84782009005000166.

Bocianowski, J.; Ksiezak, J.; Nowosad, K. Genotype by environment interaction for seeds yield in pea (Pisum sativum L.) using additive main effects and multiplicative interaction model. Euphytica, v. 215, n. 11, p. 191, 2019. https://doi.org/10.1007/s10681-0192515-1.

Carbonell, S. A. M.; Azevedo Filho, J. A. D.; Dias, L. A. D. S.; Garcia, A. A. F.; Morais, L. K. D. Common bean cultivars and lines interactions with environments. Scientia Agricola, v. 61, n. 2, p. 169-177, 2004. https://doi.org/10.1590/S0103-90162004000200008.

Ceccarelli, S.; Grando, S. Selection environment and environmental sensitivity in barley. Euphytica, v. 57, n. 2, p. 157-167, 1991. https://doi.org/10.1007/BF00023074.

Companhia Nacional de Abastecimento - Conab. Acompanhamento da Safra Brasileira de Grãos, Brasília: Conab, 2021. (v. 8 - Safra 2020/21, n. 10 - Décimo levantamento). https://www.conab. gov.br/info-agro/safras/graos/boletim-da-safra-de-graos/item/ download/38290_d7845cb956077dbc87cdc7fd8ba804b6. 28 Jul. 2021.

Cruz, C. D. Princípios de genética quantitativa. Viçosa: Universidade Federal de Viçosa, 2005. 394p.

Eisemann, R. L.; Cooper, M.; Woodruff, D. R. Beyond the analytical methodology-better interpretation and exploitation of genotypeby-environment interaction in breeding. In: Kang, M.S. (Ed.). Genotype-by-environment interaction and plant breeding. Baton Rouge: Louisiana State University, 1990. p. 108-117.

Eze, C. E.; Akinwale, R. O.; Michel, S.; Bürstmayr, H. Grain yield and stability of tropical maize hybrids developed from elite cultivars in contrasting environments under a rainforest agroecology. Euphytica, v. 216, n. 6, 2020. https://doi.org/10.1007/ s10681-020-02620-y.

Falconer, D. S.; Mackay, T. F. C. Introduction to quantitative genetics. 4. ed. Harlow: Addison Wesley Longman, 1996. 480p.

Freiria, G. H.; Gonçalves, L. S. A.; Zeffa, D. M.; Lima, W. F.; Fonseca Júnior, N. D. S.; Prete, C. E. C.; Fonseca, I. C. D. B. Bayesian AMMI applied to food-type soybean multi-environment trials. Revista Ciência Agronômica, v. 51, n. 4, p. 1-10, 2020. https://doi. org/10.5935/1806-6690.20200077. 
Gauch, H. G. A simple protocol for AMMI analysis of yield trials. Crop Science, v. 53, n.5, p. 1860-1869, 2013. https://doi.org/10.2135/ cropsci2013.04.0241.

Inabangan-Asilo, M. A.; Swamy, B. M.; Amparado, A. F.; DescalsotaEmpleo, G. I. L.; Arocena, E. C.; Reinke, R. Stability and $\mathrm{G} \times \mathrm{E}$ analysis of zinc-biofortified rice genotypes evaluated in diverse environments. Euphytica, v. 215, n. 3, p. 61, 2019. https://doi. org/10.1007/s10681-019-2384-7.

Kavalco, S. A. F.; Nicknich, W.; Vieira Neto, J.; Crispim, J. E.; Vogt, G. A.; Coimbra, J. L. M. Adaptabilidade e estabilidade de cultivares e linhagens de feijão no Estado de Santa Catarina. Agropecuária Catarinense, v. 31, n. 3, p. 62-66, 2018. https://publicacoes. epagri.sc.gov.br/RAC/article/view/260. 15 Feb. 2021.

Konzen, E. R.; Recchia, G. H.; Cassieri, F.; Caldas, D. G. G.; Berny Mier y Teran, J. C.; Gepts, P.; Tsai, S. M. DREB genes from common bean (Phaseolus vulgaris L.) show broad to specific abiotic stress responses and distinct levels of nucleotide diversity. International Journal of Genomics, v. 2019, e9520642, 2019. https://doi. org/10.1155/2019/9520642.

Lyon, A.; Tracy, W.; Colley, M.; Culbert, P.; Mazourek, M.; Myers, J.; Silva, E. M. Adaptability analysis in a participatory variety trial of organic vegetable crops. Renewable Agriculture and Food System, v. 35, n.13, p.296-312, 2019. https://doi.org/10.1017/ S1742170518000583.

Munda, S.; Sarma, N.; Lal, M.; Aromatic, M.; Group, E. P. GxE interaction of 72 accessions with three year evaluation of Cymbopogon winterianus Jowitt. using regression coefficient and Additive Main effects and Multiplicative Interaction model (AMMI). Industrial Crops and Products, v. 146, e112169, 2020. https://doi.org/10.1016/j.indcrop.2020.112169.

Mwiinga, B.; Sibiya, J.; Kondwakwenda, A.; Musvosvi, C.; Chigeza, G. Genotype $x$ environment interaction analysis of soybean (Glycine max (L.) Merrill) grain yield across production environments in Southern Africa. Field Crops Research, v. 256, e107922, 2020. https://doi.org/10.1016/j.fcr.2020.107922.
Nascimento, M.; Nascimento, A. C. C.; e Silva, F. F.; Teodoro, P. E.; Azevedo, C. F.; de Oliveira, T. R. A.; Carvalho, L. Bayesian segmented regression model for adaptability and stability evaluation of cotton genotypes. Euphytica, v. 216, n. 2, p. 30, 2020. https://doi.org/10.1007/s10681-020-2564-5.

Nowosad, K.; Liersch, A.; Poplawska, W.; Bocianowski, J. Genotype by environment interaction for oil content in winter oilseed rape (Brassica napus L.) using additive main effects and multiplicative interaction model. Indian Journal of Genetics and Plant Breeding, v. 77, n. 2, p. 293-297, 2017. https://doi.org/10.5958/09756906.2017.00039.6.

Pereira, H. S.; Bueno, L. G.; Del Peloso, M. J.; Abreu, A. D. F. B.; Moreira, J. A. A.; Martins, M.; Melo, L. Agronomic performance and stability of andean common bean lines with white grains in Brazil. Bragantia, v. 73, n. 2, p. 130-137, 2014. https://doi. org/10.1590/brag.2014.020.

$\mathrm{R}$ Core Team. A language and environment for statistical computing. Vienna: R Foundation for Statistical Computing, 2018.

Ramalho, M. A. P.; Santos, J. D.; Zimmermann, M. D. O. Genética quantitativa em plantas autógamas: aplicações ao melhoramento do feijoeiro. Goiânia: UFG, 1993. 271p.

Sarti, D. A.; Dias, C. T. S. Comparison between AMMI, W-AMMI and GGE methodology in the context of simulated data. Revista Brasileira de Biometria, v. 38, n. 3, p. 290-323, 2020. https://doi. org/10.28951/rbb.v38i3.433.

Volpato, L.; Rocha, J. R. D. A. S. D. C.; Alves, R. S.; Ludke, W. H.; Borém, A.; Silva, F. L. D. Inference of population effect and progeny selection via a multi-trait index in soybean breeding. Acta Scientiarum. Agronomy, v. 43, n.1, e44623, 2020. https://doi. org/10.4025/actasciagron.v43i1.44623.

Whitehead, W. F.; Allen, F. L. High-vs. Low-stress yield test environments for selecting superior soybean lines. Crop Science, v. 30, n. 4, p. 912-918, 1990. https://doi.org/10.2135/cropsci199 $0.0011183 \times 003000040031 x$. 